\title{
REVITALISASI WAKAF DI INDONESIA
}

\author{
Yasin \\ Sekolah Tinggi Agama Islam Negeri (STAIN) Kudus \\ e-mail: yasinmag@gmail.com
}

\begin{abstract}
One of the most beneficial teachings for others and the reward will always flow is the provision of places for the benefit of society in general, such as wells, roads, places of worship and so forth. As long as the objects taken benefit still and can be exploited by others, then the perpetrators will always get a reward from the Mercy or who is now better known with the teachings of waqf. Since humans are social beings, it is natural that a problem is solved together. Certain needs are sought to be fulfilled on their own and when it is impossible, the solution is done by others or together, or by those with a high social sense. The cash waqf movement is an extraordinary asset of Muslims if it is managed and developed professionally. This movement should begin immediately without considering anything else that is not a principle. Wakaf cash movement will be more powerful when coupled with the movement of zakah mal.
\end{abstract}

Keywords: Waqf, Revitalization, and Empowerment

\section{Pendahuluan}

Al-Quran surat al-Maidah ayat 3 menjelaskan bahwa agama Islam dinyatakan sebagai agama yang telah sempurna. 
Konsekuensinya segala hal yang telah dibawa oleh para rasul sebelumnya harus diakomodir dan siap menjawab persoalan manusia di masa yang akan datang. Beberapa syariat para rasul yang sampai saat sekarang masih eksis cukup banyak, seperti solat, zakat dan puasa. Tidak ada seorang rasul yang tidak memiliki ajaran tentang solat karena solat merupakan komunikasi manusia dengan Khaliqnya sebagai bentuk pengakuan dan penghambaan kepada yang Maha Kuasa. Solat juga merupakan pengakuan seorang manusia sebagai makhluk atas al-Khaliq sebagai pencipta.

Sementara ajaran zakat merupakan ajaran yang mengarahkan manusia untuk mengerti dan memahami kebutuhan orang lain. Harta yang didapatkan bukan sematamata milik pribadi, pemiliknya disarankan dan bahkan diwajibkan kepada orang-orang tertentu yang telah memenuhi syarat untuk menyalurkan sebagian hartanya kepada orang lain yang kebetulan kebutuhannya tak tercukupi dari hasil usahanya. Intinya, zakat adalah kewajiban yang dibebankan kepada orang yang berkecukupan agar menyisihkan sebagian hartanya untuk orang-orang lemah. Ajaran ini sesungguhnya menuntun, dan mengarahkan manusia agar mengerti bahwa keberhasilan seseorang itu tidak bisa terlepas dari bantuan orang lain yang kebetulan lemah dari sisi perekonomian. Tak seorang pun orang kaya yang tidak membutuhkan bantuan orang miskin; justru semakin kaya seseorang, semakin banyak ia membutuhkan bantuan orang lain. Jumlah pembantunya semakin banyak karena setiap pekerjaan harus ada yang menangani secara khusus. Maka tepat sekali jika orang kaya diwajibkan untuk mengerti kebutuhan orang-orang lemah.

Ajaran tentang puasa juga dimiliki oleh umat terdahulu meskipun tata caranya sedikit berbeda namun pada prinsipnya adalah sama, yakni mengurangi hal-hal yang menjadi kesenangan jasmani manusia, terutama hal-hal yang berhubungan dengan makan minum dan seks. Dua hal ini merupakan kesenangan 
melebihi yang lain. Oleh karenanya, ketika manusia mampu mengendalikan diri dari makan-minum dan seks, maka menahan diri dari selain keduanya pasti lebih ringan dan mudah baginya (Muhammad Nawawi, t.t.: I/47). Jika seorang manusia dapat mengendalikan dirinya dari hal-hal yang dilarang oleh Allah SWT, maka dapat dijamin bahwa orang tersebut menjadi orang yang bertakwa sesuai Al-Quran surat al-Baqarah akhir ayat 183.

Jika diperhatikan secara cermat, ajaran Allah SWT dapat dikelompokkan menjadi dua, yakni ajaran yang berhubungan dengan Yang Maha Segalanya, dan ajaran yang terkait dengan hubungan antara manusia dengan makhluk lain, baik manusia atau yang lain. Manusia dituntut memiliki hubungan baik dengan Allah SWT dan hubungan baik dengan sesama makhluk terutama sesama manusia. Hubungan baik dengan salah satu (vertikal saja atau horizontal saja) dianggap kurang. Allah SWT berfirman yang artinya: "Mereka diliputi kehinaan di mana saja mereka berada kecuali jika mereka (berpegang) pada tali (agama) Allah dan tali (perjanjian) dengan manusia." (QS. Ali Imran, 112)

Hubungan kita dengan Tuhan, Allah SWT yang sering kita kenal dengan istilah ibadah mahdzah dapat dicontohkan solat, dan puasa. Sedang perbuatan baik kita kepada sesama manusia disebut hablun min an-nas. Salah satu ajaran yang sangat bermanfaat bagi sesama dan pahalanya akan selalu mengalir adalah penyediaan tempat-tempat untuk kepentingan masyarakat secara umum, seperti sumur, jalan, tempat ibadah dan lain sebagainya. Selama benda yang diambil manfaatnya masih dan bisa dimanfaatkan oleh orang lain, maka pelakunya akan selalu mendapat kiriman pahala dari Sang Maha Kasih. Karena manusia adalah makhluk sosial, wajar kiranya sebuah persoalan diselesaikan secara bersama. Kebutuhan tertentu diupayakan dapat dipenuhi sendiri dan ketika tidak mungkin, solusinya dilakukan oleh orang lain atau secara bersama, atau oleh mereka yang mempunyai rasa sosial tinggi. Rasulullah SAW pernah bersabda bahwa sebaik-baik 
manusia adalah yang paling bermanfaat bagi yang lain (as-Suyuti, t.t: II/9). Hal seperti ini pernah terjadi di masa Mesir Kuno.

Di Mesir, Raja Ramses II mendermakan tempat ibadah "Adibus" yang arealnya sangat luas. Di Negara itu, harta waris dikelola oleh orang tertentu dan hasilnya diberikan kepada keluarganya dan keturunannya dan seterusnya. Si pengelola berhak mendapat bagian dari hasil harta yang dikelola itu. Yang perlu mendapat perhatian adalah bahwa harta asalnya tidak boleh habis; harta yang dibagi hasil dari pengelolaan itu (Depag, 2007: 7). Pengelolaan harta waris seperti tersebut di atas mirip dengan yang kali ini dikaji, yakni wakaf keluarga. Pengelolanya berhak mendapat bagian dari hasil pengelolaannya.

Praktek pembentukan lembaga semacam wakaf itu dilanjutkan oleh Nabi Muhammad SAW dengan memberi istilah "wakaf", yang mempunyai arti bahasa "berhenti". Yang berhenti pokoknya, sedang hasilnya yang dimanfaatkan dan diberdayakan. Tidak terlalu salah jika dikatakan bahwa lembaga keagamaan yang disebut wakaf ini lanjutan dari budaya umat sebelum Nabi Muhammad SAW. Dari pengertian bahasa itu ada di antara para ulama yang berpendapat bahwa harta wakaf itu tidak boleh ditarik kembali oleh si wakif (orang yang mewakafkan). Ulama yang lain juga ada yang berpendapat lain, yakni bahwa wakaf itu boleh dibatasi waktu, seperti meminjamkan atau memberi hak pakai. Tulisan ini secara khusus memaparkan pentingnya wakaf dan pemberdayaan kembali di Indonesia. Disebut pemberdayaan kembali, karena lembaga keagamaan yang satu ini (wakaf) di negara lain pernah menjadi budaya yang sangat bermanfaat dan sangat berdaya sampai sekarang. Hanya saja lembaga itu di Indonesia belum banyak diberdayakan.

\section{Pembahasan}

\section{Dasar disyariatkannya wakaf}

Mengawali pembahasan tentang pemberdayaan wakaf, kita tidak bisa mengesampingkan dasar atau dalil tentang eksistensi 
wakaf itu sendiri. Ayat Al-Quran yang sering digunakan untuk membicarakan wakaf adalah surat Ali Imran ayat 92 yang artinya: "Kamu sekali-kali tidak sampai kepada kebajikan (yang sempurna), sebelum kamu menafkahkan sehahagian harta yang kamu cintai. dan apa saja yang kamu nafkahkan Maka Sesungguhnya Allah mengetahuinya." (QS. Ali Imran: 92)

Ketika ayat ini turun kepada Rasulullah SAW dan disampaikan kepada para sahabat, maka mereka langsung memberikan respon karena mereka takut tidak mendapat kebajikan sebagaimana digambarkan ayat tersebut.

Dalam sebuah hadis telah diriwayatkan dari Ibnu Umar bahwa Umar bin al-Khattab mendapat bagian tanah di wilayah Khaibar, ia minta saran kepada Rasulullah SAW seraya berkata: Hai Rasulullah, saya telah mendapat bagian tanah di wilayah Khaibar, sebidang tanah yang paling saya sukai, perintah apa yang engkau berikan kepada saya terkait dengan tanah tersebut. Rasulullah SAW menjawab: Jika kamu setuju, tahanlah pokoknya dan sedekahkan hasilnya. Maka Umar pun menyedekahkan tanah tersebut kepada para orang fakir, anggota keluarga, budak, para tamu, dan ibnu sabil, dengan syarat tidak boleh dijual, dihibahkan, dan tidak boleh diwariskan (Asy-Syaukani: III-j.6/120)

Dalam riwayat lain disebutkan: Dari Ibnu Umar, Sahabat Umar berkata kepada Nabi Muhammad SAW terkait dengan masalah harta rampasan: Sesungguhnya saya telah mendapat bagian ganimah di daerah Khaibar, saya belum pernah mendapat harta sebaik itu. Saya bermaksud menyedekahkan harta itu. Nabi SAW bersabda: Tahan pokoknya dan sedekahkan hasilnya (HR. an-Nasai)

Satu ayat Al-Quran dan dua hadis di atas dirasa cukup memberikan petunjuk terkait eksistensi wakaf dalam Islam. Yang pasti, wakaf dalam Islam pada awalnya justru menekankan dalam bidang ekonomi, dan kesejahteraan umat, bukan dalam penyiapan tempat ibadah mahdzah, seperti masjid, dan musalla. 
Wakaf sahabat Umar sebagai respon terhadap Al-Quran surat Ali Imran ayat 92 itu mendorong sahabat-sahabat yang lain mengikutinya. Abu Talhah mewakafkan kebun kesangannya, di Bairuha, Abu Bakar mewakafkan sebidang tanahnya di Makkah, yang diperuntukkan kepada keluarganya dan keturunannya yang datang ke Makkah; sahabat Usman mewakafkan hartanya di Khaibar.

Ajaran wakaf ini disyariatkan dua tahun setelah Rasulullah hijrah ke Madinah. Di kalangan fuqaha (ahli fiqh) terdapat dua pendapat tentang siapa sesungguhnya orang pertama kali yang melakukan syariat wakaf ini, yaitu:

1. Nabi Muhammad SAW

Pendapat ini dipegangi oleh para sahabat Ansar.

Nabi sendiri yang mempraktekkan ajaran wakaf ini dengan mewakafkan tanahnya untuk dibangun masjid di atasnya. Pada tahun ketiga hijrah, Nabi saw mewakafkan tujuh kebun kurma di Madinah, yang di antaranya kebun A'raf, Safiyah, Dalal, dan Barqah (Depag: 2007: 9)

2. Umar bin al-Khattab

Pendapat ini dipegangi oleh sahabat Muhajirin. (AsySyaukany, III-j.6/122). Pendapat ini diriwayatkan oleh Imam Ahmad dari Ibnu Umar.

Kedua pendapat ini sulit diverifikasi lantaran dasar yang dipakai hanya hadis yang tidak terdapat penjelasan kapan hadis itu disabdakan oleh Nabi Muhammad SAW. Namun AsySyaukany cenderung memilih pendapat yang pertama. Hal ini terbukti bahwa setelah meriwayatkan kedua pendapat di atas, beliau mengutip tulisan al-Waqidy yang menyatakan bahwa wakaf pertama kali dalam Islam adalah tanah milik Mukhairiq, yang diwasiatkan kepada Nabi Muhammad SAW. Setelah Mukhairiq meninggal dunia, tanah itu dibalik nama oleh Nabi Muhammad SAW, kemudian diwakafkan untuk kepentingan 
umat utamanya para fakir-miskin (Esposito, John L, Editor, 2001: 6/146-147).

Satu hadis lagi yang justru peling sering digunakan oleh para kiai dalam mengkampanyekan wakaf adalah: "Jika seorang manusia meninggal dunia, maka putuslah amalnya kecuali tiga hal, yaitu: sedekah yang mengalir (pahalanya), ilmu yang bermanfaat, dan anak saleh yang mendoakan kepadanya." (HR. Jama'ah kecuali Bukhari dan Ibn Majah) (Syaukani, VI/120)

Bagi orang tua yang usianya telah menghadapi senja, 50 (lima puluh) tahun ke atas biasanya mulai memikirkan nasib dirinya sendiri untuk menghadapi saat-saat yang orang lain tidak dapat membantunya kecuali amalnya sendiri, kematian. Khususnya orang tua yang merasa kurang berhasil dalam mendidik anak-anaknya dan merasa tidak termasuk kelompok kiai atau bu nyai (punya ilmu agama yang cukup). Maka ia lebih semangat melakukan amal yang pahalanya mengalir, yang oleh para kiai diterjemahkan menjadi "wakaf". Mereka tidak dapat mengandalkan anak-anaknya yang menurut perhitungannya kurang mengerti kebutuhan orang tua yang telah meninggal dunia. Di samping ia tidak dapat mengandalkan ilmu yang dimanfaatkan orang lain, karena mereka merasabukan kelompok itu.

\section{Wakaf dalam sejarah}

1. Wakaf Sebelum Islam

Ide wakaf sama tuanya dengan usia manusia. Para ahli hukum Islam menyatakan bahwa wakaf yang pertama kali adalah bangunan Ka'bah di tanah suci Makkah yang disebut dalam AlQuran surat Ali Imran ayat 96 sebagai rumah ibadah pertama yang dibangun oleh umat manusia. Ayat yang menjelaskan hal itu adalah: "Sesungguhnya rumah yang mula-mula dibangun untuk (tempat beribadat) manusia, ialah Baitullah yang di Bakkah (Mekah) yang diberkahi dan menjadi petunjuk bagi semua manusia." (QS. Ali Imron: 96) 
Ahli Kitab mengatakan bahwa rumah ibadah yang pertama dibangun adalah Baitul Maqdis, di Palestina. Ayat ini diturunkan untuk membantah pandangan ahlu kitab tersebut.

Dalam prakteknya, semua masyarakat dunia telah menetapkan tanah dan bangunan tertentu sebagai tempat ibadah. Selama beberapa abad, kuil, gereja, dan bentuk bengunan lainnya didirikan dan diperuntukkan sebagai tempat ibadah. Lebih dari itu penguasa Mesir menetapkan tanah untuk dimanfaatkan oleh para Rahib, sedangkan orang-orang Yunani dan Romawi kuno menyumbangkan harta benda mereka untuk perpustakaan dan pendidikan. Kini ide mengenai wakaf dikenal luas dan dipraktikkan di mana-mana.Amal sejenis wakaf juga ditemukan di Amerika Utara dengan nama Yayasan, khususnya yayasan keagamaan dan amal (Esposito, 2001: 146-147)

2. Pengelolaan Wakaf di Awal Islam

Dalam sejarah Islam, wakaf keagamaan pertama adalah Masjid Quba`di Madinah. Masjid ini dibangun oleh Nabi saw pada saat kedatangannya di daerah itu tahun 622. Sampai kini masjid tersebut masih berdiri kokoh di tempat yang sama dengan bangunan yang telah direnovasi dan diperluas. Selang enam bulan setelah masjid Quba' dibangun, didirikan masjid nabawi di tengah kota Madinah. Masjid serta tanah dan bangunan yang secara eksklusif menyediakan penghasilan untuk pemeliharaan dan pendanaan operasional kegiatan yang dilaksanakan di masjid itu termasuk kedalam kategori wakaf keagamaan. Ini adalah bentuk wakaf yang pertama.

Bentuk kedua wakaf adalah wakaf derma (filantropis). Tujuannya untuk menyantuni fakir miskin dan kepentingan umum secara luas dengan mendanai lembaga dan aktivitas seperti perustakaan, riset keilmuan, pendidikan, pelayanan kesehatan, pemeliharaan binatang, dan lingkungan hidup. Wakaf juga dapat digunakan untuk pinjaman usaha kecil, pembangunan, dan pemeliharaan taman, jalan raya, jembatan, dan bendungan. 
Memperhatikan beberapa hadis tersebut di atas, kita dapat mengambil pengertiannya bahwa wakaf di awal Islam diarahkan untuk kesejahtaraan bersama/ umat, atau paling tidak kesejahteraan keluarga dan kerabat dekat siwakif. Wakaf yang dilakukan oleh Abu Bakar r.a misalnya, untuk keluarga dekat dan keturunannya, sementara wakaf sahabat Umar r.a. untuk kepentingan umum, mulai dari fakir, miskin, keluarga dekat, para budak, serta para musafir yang melewati kebun, tempat harta wakaf itu berada.

Adapun wakaf bentuk ketiga dimulai tak lama setelah Nabi Muhammad SAW. wafat, yakni pada masa kholifah Umar bin al-Khattab (635-645). Ketika Umar memutuskan untuk membuat dokumen tertulis mengenai wakafnya di Khaibar, dia mengundang beberapa sahabat untuk menyaksikan penulisan dokumen tersebut. Jabir, sahabat yang lain, mengatakan bahwa ketika dokumen tersebut dibuat, banyak pemilik tanah yang ikut memberikan wakaf. Beberapa di antara mereka menambahkan syarat bahwa hasil dari kebun wakaf berupa buah-buahan dan manfaat yang lain diberikan terutama kepada anak-anak serta ahli waris si wakif. Kalau ada kelebihan dapat diberikan kepada para fakir miskin. Wakaf demikian ini disebut wakaf keluarga.

3. Pengelolaan Wakaf pada Masa Umayah dan Abasiyah

Pada masa Dinasti Umayah dan dinasti Abasiyah, praktik wakaf semakin berkembang. Banyak orang yang ingin mewakafkan hartanya. Wakaf tidak hanya diperuntukkan kepada fakir miskin, tetapi juga digunakan sebagai modal untuk membangun lembaga pendidikan, perpustakaan dan membayar gaji para stafnya gaji para guru, dan beasiswa untuk para siswa dan mahasiswanya.

Pada masa khalifah Hisyam bin Abdul Malik dari dinasti Umayah, yang menjadi hakim di Mesir adalah Taubah bin Gar al-Hadramy. Al-Hadramy memiliki perhartian yang besar terhadap pengembangan wakaf, karena itu ia berinisiatif untuk 
membentuk lembaga pengelola wakaf sebagaimana lembaga lainnya yang berada di bawah pengawasan hakim. Lembaga wakaf inilah yang pertama kali dilakukan dalam administrasi wakaf di Mesir dan di Negara Islam. Pada saat bersamaan, alHadramy juga mendirikan lembaga pengelola wakaf di Basrah, dan Irak. Dan sejak itulah lembaga pengelola wakaf berada di bawah pengawasan Departemen Kehakiman, sehingga wakaf dapat dikelola secara baik dan hasilnya disalurkan kepada mereka yang berhak membutuhkan. Pada masa khalifah Umar bin Abdul Aziz sebagaimana diceritakan oleh Yahya bin Sa id dan dikutip kembali oleh Ahmad Syalaby: Saat itu Yahya mendapat tugas mengumpulkan zakat dan infak. Setelah tugas itu saya lakukan dan selanjutkan akan saya bagi dan ternyata saya tidak menemukan orang fakir dan miskin. Mereka berkata Umar bin Abdul Aziz telah membuat kami kaya (Ahmad Syalaby, 1978: II/88). Sementara pada masa dinasti Abasiyah lahir lembaga pengelola wakaf yang dikenal dengan nama "Shadr al-Wukuf."

4. Pengelolaan dan Pemanfaatan Wakaf di Negara-negara Muslim

Sub bab pengelolaan dan pemenfaatan wakaf di Negaranegara Muslim ini penting untuk dipaparkan agar para pembaca mendapat gambaran bagaimana ajaran wakaf ini dilaksanakan di Negara-negara, yang di sana terdapat penduduk atau warga Negara yang beragama Islam/Muslim meskipun tidak mayoritas dan berhasil memberdayakan wakaf untuk kepentingan umum.

a. Singapura

Singapura, sebagai Negara yang penduduk muslimnya tidak lebih dari $15 \%$ telah berhasil memberdayakan wakaf. Dari 101 aset wakaf, 68 dikelola oleh Warees, sebuah lembaga yang khusus menangani wakaf dengan total valuasi senilai 707 juta dollar AS per 31 Desember 2016. Penghasilan dari pengelolaan wakaf property ini didistribusikan ke beberapa pihak. Tiga juta dollar AS telah didistribusikan kepada para penerima manfaat 
wakaf (Mauquf Alaih). Penerima manfaat terbesar adalah masjid (62\%), lembaga luar negeri, biasanya Negara asal pemberi wakaf (13\%), madrasah (9\%), organisasi sosial, seperti panti sosial dan lain-lain (5\%), orang-orang miskin (4\%), untuk pemakaman orang miskin (3 \%), lain-lain (3 \%). (Vicky Vendy, 2017)

b. Turki

Salah satu Negara yang telah berhasil mengelola wakaf dengan baik adalah Turki. Pengelolaan wakaf di Turki sangat luar biasa, yang kalau dirunut sejarahnya dimulai sejak masa Usmaniyah. Pada tahun 1925 saja, harta wakaf di Turki mencapai $3 / 4$ dari lahan produktif di Negara itu. Adapun pemanfaatan dana wakaf ini untuk pelayanan kesehatan, pendidikan dan penyelesaian masalah sosial.

c. Mesir

Kemajuan wakaf di Mesir sudah diragukan lagi. Lahirnya Diwan al-Auqaf, sebuah lembaga yang dibentuk untuk mengurus harta wakaf menunjukkan keinginan pemerintah untuk mengelola wakaf secara produktif. Pada tahun 1913 M, tepatnya tanggal 20 November Diwan al-Auqaf menjadi departemen, sehingga masalah wakaf di Mesir diurus langsung oleh Kementerian (Wizarah al-Auqaf) (Ahmad Junaidi, 2007: 32-34). Terakhir pada tahun 1971 pemerintah Mesir membentuk Badan Wakaf yang bertugas melakukan kerjasama dalam membuat rencana pengembangan harta wakaf, serta mendistribusikan hasil kepada yang berhak menerimanya.

Untuk mengembangkan harta wakaf secara produktif, Badan Wakaf ini menitipkan harta wakaf di Bank-bank Islam. Di samping itu, Badan Wakaf juga berpartisipasi dalam mendirikan Bank-bank Islam, bekerjasama dengan sejumlah perusahaan dan membeli saham dan obligasi perusahaan penting dan memanfaatkan lahan kosong agar menjadi produktif. 
Yasin

\section{Paradigma wakaf}

1. Paradigma Lama Pengelolaan Wakaf

a. Wakaf Lisan (Tradisional)

Referensi tentang ajaran Islam masuk ke Indonesia bersama dengan masuknya si pembawa dakwah itu, yaitu pandangan ulama Syafiiyah. Dengan begitu, yang mewarnai pandangan masyarakat muslim Indonesia adalah mazhab Syafi'i. Shahib almazhab yang satu ini berpendapat bahwa melakukan wakaf itu cukup dengan lisan. Saksi dan pencatatan bukan merupakan kewajiban, dan bukan syarat. Oleh karenanya kebanyakan wakaf di Indonesia dianggap cukup dengan ikrar wakaf secara lisan tanpa saksi dan tanpa pencatatan. Akibatnya, banyak harta benda wakaf yang hilang tak terurus, atau bahkan sengaja disembunyikan oleh pihak yang tidak bertanggungjawab.

Satu hal lagi yang yang tidak kalah pentingnya adalah kepercayaan dari pihak wakif kepada nazir, yang diserahi menjaga keberlangsungan harta wakaf itu. Penjagaan keberlangsungan wakaf ini tidak diberengi dana atau biaya yang dibutuhkan dalam penjagaan itu. Sehingga nazir tidak pernah mendapat sesuatu dari si wakif atau hasil dari pengelolaan harta wakaf tersebut, di samping kebanyakan harta wakaf selama ini berupa tanah yang di atasnya didirikan bangunan yang digunakan untuk beribadah atau sarana pendidikan, dasar yang sudah barang pasti tidak profit.

b. Nazir Tanpa Penghargaan

Istibdal al-mauqufbih (pertukaran harta wakaf) tidak dikenal dalam buku-buku atau kitab-kitab Syafiiyah kecuali dalam kondisi terpaksa. Hal ini juga menjadi faktor yang mendukung sulitnya harta wakaf diberdayakan. Para pengikut mazhab sama sekali tidak mau atau tidak berani bergeser dari pendapat mazhabnya. Meskipun sesungguhnya pendapat lain itu sangat bermanfaat baik untuk kepentingan penjagaan harta wakaf itu atau untuk memberi gaji kepada para nazir yang diberi tanggungjawab yang 
sangat berat tapi mulia itu. Nazir masjid yang berada di tempat strategis untuk digunakan berbisnis tetap saja tidak berani melakukan inovasi agar masjid dapat terjaga dengan baik dan bahkan ia dapat mengambil sebagian hasil.

Satu hal lagi yang tidak kalah pentingnya adalah rendahnya sumber daya manusia, yang dalam hal ini nazir. Mereka berpendapat bahwa tugas nazir hanya sekedar menjaga keberadaan wakaf yang diserahkan kepada mereka. Perbaikan benda wakaf biasanya dilakukan oleh nazir dengan hartanya sendiri. Jika dirasa kurang, nazir minta sumbangan masyarakat sekitar secara sukarela.

2. Paradigma Baru Pengelolaan Wakaf

a. Sertifikasi Harta Wakaf

Undang-undang No. 41 Tahun 2004 tentang wakaf telah mengatur hampir semua hal terkait dengan masalah wakaf. Kewajiban mensertifikatkan tanah wakaf sesungguhnya sudah diatur dalam beberapa peraturan sebelum Undang-undang yang telah lahir dua belas yang lalu itu. Namun paradigma lama masih saja sulit untuk ditinggalkan, karena mengubah sebuah pemahaman itu tidak semudah membalik telapak tangan. Bahkan jika pemahaman itu tidak langsung dari pembacaan referensi, maka perubahan itu lebih sulit. Jika pengertian tentang wakaf dengan paradigma lama itu diterima dari seorang Kiai, maka pergeseran makna wakaf dengan paradigma baru itu akan lebih mudah dari Kiai yang sama atau Kiai yang dianggap mempunyai ilmu agama yang melebihi Kiai yang pertama.

Memberi pengertian kepada para nazir produk lama bahwa pensertifikatan tanah wakaf itu sangat penting ternyata tidak mudah.

b. Wakaf Produtif

Uang 
Wakaf uang tidak perlu dipersoalkan lagi, karena uang yang diwakafkan itu tidak langsung dimanfaatkan. Uang yang terkumpul itu diinvestasikan, kamudian hasilnya diberdayakan untuk kepentingan sesuai keinginan siwakif. Lembaga Keuangan Syariah yang mendapat amanat mengumpulkan wakaf uang harus mengelompokkan sesuai tujuan wakif sehingga dalam pemberdayaan hasil wakaf uang itu dapat dipertanggungjawabkan. Karena menggeser tujuan wakaf itu tidak mudah, bahkan pada prinsipnya tidak boleh kecuali dalam kondisi darurat atau terpaksa.

Untuk menghindari hal-hal yang tidak diinginkan, nazir dapat mengkondisikan si wakif dengan memberi saran agar tujuan wakaf diarahkan ke kepentingan umat secara umum, atau untuk fakir miskin tanpa pembatasan yang menyulitkan.

\section{Tempat yang Strategis}

Tempat setrategis merupakan modal yang cukup tinggi nilainya utamanya dalam berbisnis. Jika nazir dapat mengelola harta wakaf dengan baik, maka tempat itu akan menghasilkan keuntungan yang besar pula. Sebagai contoh di tempat yang strategis itu didirikan beberapa unit gedung untuk disewakan menjadi perkantoran atau penginapan/ hotel atau yang lain. Hasilnya didistribusikan sesuai tujuan yang ditunjuk oleh siwakif.

Sebelum dibangun beberapa unit gedung, nazir bisa memanfaatkan tempat itu sebagai tempat parkir sepeda motor atau mobil. Dengan begitu, nazir dapat memberdayakan tanah wakaf tersebut untuk menjaga keutuhan harta wakaf dan bahkan memberdayakannya untuk kepentingan yang lebih besar.

c. Manajemen Pengelolaan Wakaf

Setelah sinazir dapat mengelola harta wakaf dan memberdayakannya, tugas berikutnya yang tidak kalah 
pentingnya dan telah menunggu adalah memanaj secara baik. Hasil harta wakaf harus dibukukan secara baik dan didistribusikan sesuai kehendak siwakif yang tercantum dalam akte ikrar wakaf.

\section{Kondisi riil pengelolaan wakaf di Indonesia}

Sampai saat ini, pengelolaan harta wakaf di Indonesia belum sesuai harapan. Harta wakaf belum terdata secara baik, belum terdatanya harta wakaf disebabkan beberapa faktor. Di antaranya adalah kurangnya kesadaran dari pihak siwakif atau dari para nazir yang diserahi mengelola harta wakaf itu. Ikrar wakaf yang dilakukan oleh siwakif tidak mengikuti prosedur yang ditetapkan dalam Undang-undang wakaf. Siwakif mengikrarkan wakafnya hanya secara lisan tanpa disertai pencatatan yang memadahi. Akibatnya wakaf itu tidak diketahui oleh pihak pemerintah setempat, yang dalam hal ini wakil staf yang menangani masalah pajak.

Satu hal lagi yang tidak kalah pentingnya adalah kurangnya dorongan dari pihak tokoh masyarakat, utamanya tokoh agama. Sosialisasi pentingnya sertifikasi tanah wakaf akan membantu kelancaran tertibnya wakaf di daerah masing-masing. Sebab kebanyakan masyarakat tidak mengerti bahwa hal itu sangat penting khususnya untuk menjaga kelestarian tanah wakaf yang ada.

Tujuan wakaf oleh siwakif juga menjadi faktor tidak produktifnya tanah wakaf. Sementara ini tujuan wakaf masih berkisar untuk mendirikan tempat ibadah dan sarana pendidikan. Hampir di setiap desa terdapat tanah wakaf, namun peruntukannya untuk mendirikan musalla, masjid, dan madrasah tempat anak-anak mereka belajar agama. Wakaf untuk mendanai operasional kegiatan keagamaan di desa itu belum ada yang memperhatikan. Kegiatan keagamaan didanai oleh masyarakat secara insidental. 
Yasin

\section{Urgensi revitalisasi wakaf di Indonesia}

Di samping zakat, wakaf adalah lembaga keagamaan yang berpotensi sangat besar dalam pengumpulan dana umat untuk kepentingan umum. Jika orang Islam yang berpenghasilan menengah ke atas berjumlah satu juta, misalnya dan yang bersedia menyisihkan hartanya untuk diwakafkan 100.000,- (seratus ribu) per bulan sebanyak 100.000 orang, maka dalam waktu satu tahun sudah terkumpul dana wakaf Rp 120.000.000.000,- (seratus dua puluh milliard rupiah). Jika gerakan wakaf ini ditangani dengan manajemen yang professional, maka dana yang terkumpul akan lebih dari perkiraan tersebut. Dan jika uang sebanyak itu dikembangkan, diinvestasikan, maka dalam jangka waktu yang tidak terlalu lama hasilnya sudah dapat dirasakan.

\section{Wakaf Uang}

Penulis yakin bahwa tidak ada seorang muslim di dunia ini yang tidak berkeinginan mendermakan sebagian hartanya untuk orang lain. Jika pernyataan ini benar, maka muncul pertanyaan, siapa yang dapat dipercaya menangani dan mengelola harta itu. Pertanyaan berikutnya adalah bagaimana harta itu dikumpulkan, dan bagaimana harta itu dikelola agar harta itu tidak habis. Pertanyaan-pertanyaan itu sesungguhnya tidak perlu muncul, karena Undang-undang No. 41 tahun 2004 telah mengaturnya.

Yang belum adalah sosialisasi eksistensi Lembaga Keuangan Syariah yang dipercaya menerbitkan sertifikat wakaf uang lengkap dengan formulir/blangko sertifikat uang. Sampai saat tulisan ini diedit, Lembaga keuangan Syariah Penerima Wakaf Uang (LKSPWU) di Kabupaten Grobogan dan Kudus belum menampakkan dirinya, sehingga wakaf uang di kedua kabupaten itu belum berjalan. Masyarakat awam di kedua kabupaten tersebut sama sekali belum mengerti tata cara mewakafkan uang (wawancara dengan beberapa tokoh masyarakat di kedua kabupaten tersebut akhir tahun 2017) 
2. Lembaga Keuangan Syariah Penerima Wakaf Uang (LKSPWU)

Sesuai Undang-undang No 41 Tahun 2004 dan Peraturan Pemerintah No. 42 Tahun 2006, hanya Lembaga Keuangan Syariah yang ditunjuk Menterilah yang berhak menerima wakaf tunai. Lembaga Keuangan Syariah itu harus mengajukan permohonan kepada Menteri dengan melengkapi persyaratan lainnya, yakni:

a) Melampirkan anggaran dasar dan pengesahan sebagai badan hukum;

b) Memiliki kantor operasional di wilayah Republik Indonesia;

c) Bergerak di bidang keuangan syariah; dan

d) Memiliki fungsi menerima titipan (wadi'ah).

Di kabupaten/kota belum banyak LKS yang mengajukan sebagai Penerima Wakaf Uang. Sosialisasi wakaf uang akan sangat terhambat manakala di tempat sosialisasi belum ada LKS yang berhasil mendapat ijin dari Menteri sebagai LKS-PWU. Sesungguhnya prosedur penunjukan LKS menjadi LKS-PWU cukup sederhana dan tidak terlalu lama.

Agar proses penunjukan LKS sebagai LKS-PWU lebih cepat, maka Badan Wakaf Indonesia (BWI) wajib memberikan pertimbangan kepada Menteri paling lambat 30 (tiga puluh) hari kerja setelah LKS memenuhi persyaratan. Setelah menerima saran dan pertimbangan BWI, Menteri paling lambat 7 (tujuh) hari kerja menunjuk LKS atau menolak permohonan dimaksud. (Dirjen Bimas Islam, 2007: 44). Dengan begitu, tidak lebih dari 40 (empat puluh) hari kerja, LKS sudah dapat mengerti apakah permohonannya sebagai PWU disetujui atau ditolak. Jika di setiap kabupaten terdapat minimal satu LKS-PWU, penulis yakin bahwa pengumpulan dana melalui wakaf tunai akan segera mengalir, dan pada waktu yang tidak terlalu lama dana yang terkumpul dapat diinvestasikan, yang hasilnya dapat diberdayakan. 
3. Manajemen Pengelolaan Wakaf .

Selanjutnya tugas bersama yang sudah menanti adalah pengelolaan wakaf. Nazir harus telah piawai dalam mengelola wakaf secara produktif. Lembaga survey diperlukan untuk menentukan investasi di bidang apa harta wakaf itu diinvestasikan jika tidak dapat mengelola dan mengembangkannya. Kerjasama dengan perusahaan yang cukup mapan juga dapat dilakukan, yang selanjutnya hasilnya dikelola dengan manajemen yang transparan.

4. Penyiapan SDM

Salah satu hal yang juga harus disiapkan dalam proses pengelolaan wakaf produktif adalah kehandalan nazir dalam mengelola harta wakaf. Handal dalam menjalin kemitraan dengan pengusaha yang amanah dan handal dalam mengembangkan harta wakaf agar lestari dan hasilnya didayagunakan.

5. Peran Tokoh Agama dalam Pengelolaan Wakaf

Satu hal lagi yang tidak kalah pentingnya adalah peran tokoh masyarakat utamanya tokoh agama dalam membangkitkan masyarakat dalam beramal melalui wakaf uang. Hal ini dirasa penting karena masyarakat itu selalu mengikuti arahan tokohnya. Jika kemampuan masyarakat masih berada di level yang rendah dan belum mencapai batas yang ditentukan dalam berwakaf uang, nazir harus pro aktif dengan mengumpulkan uang di tangan bendahara, yang selanjutnya didaftarkan ke Lembaga Keuangan Syariah setelah memenuhi batas yang ditentukan. Keberanian seperti ini harus mulai dirintis dari bawah dengan dorongan dan peran tokoh masyarakat.

\section{Simpulan}

Gerakan wakaf tunai merupakan asset umat Islam yang luar biasa jika dikelola dan dikembangkan secara professional. Gerakan ini harus segera dimulai tanpa mempertimbangkan hal 
lain yang bukan prinsip. Gerakan wakaf tunai akan lebih dahsyat manakala digandeng dengan gerakan zakat mal.

\section{Daftar Pustaka}

A. Qadri Azizy, Membangun Fondasi Ekonomi Umat: Meneropong Prospek Berkembangnya Ekonomi Islam, Pustaka Pelajar, Yogyakarta, 2004.

Ahmad Djunaidi dan Thobieb al-Asyhar, Menuju Era Wakaf Produktif, Cet. Ke-4, Mumtaz Publishing, Depok, 2007.

Direktorat Pemberdayaan Wakaf, Strategi Pengembangan Wakaf Tunai di Indonesia, 2007.

Dirjen Bimas Islam, Pedoman Pengelolaan Wakaf Tunai, Direktorat Pemberdayaan Wakaf, Jakarta, 2007;

Jalal ad-Din Abd ar-Rahman As-Suyuti, al-Jami`as-Sagir fi Ahadis al-Basyir an-Nadzir, juz II, t.t.

Muhammad Nawawi Al-Jawy, Marah Labid Tafsir an-Nawawy, Juz. I, Syirkah Maktabah Ahmad bin Sa'ad bin Nabhan wa Auladuh, Surabaya, t.t.

Peraturan Pemerintah Nomor 42 Tentang Pelaksanaan UU Nomer 41 tahun 2004.

Undang-undang Nomor 41 Tahun 2004 tentang Wakaf 
Yasin

Halaman ini bukan sengaja untuk di kosongkan 